\title{
EKSPERIMEN MODEL PEMBELAJARAN TEAMS GAMES TOURNAMENT (TGT) BERBANTUAN MEDIA KERANJANG BIJI-BIJIAN TERHADAP HASIL BELAJAR MATERI PERKALIAN DAN PEMBAGIAN SISWA KELAS II SDN SAPTORENGGO 02
}

\author{
Amanda Purwandari ${ }^{1}$, , Dyah Tri Wahyuningtyas ${ }^{2}$ \\ 1 Universitas Kanjuruhan Malang \\ 2 Universitas Kanjuruhan Malang
}

\begin{abstract}
Abstrak
Learning math using rote memorization, making it difficult students understand the basic concepts of multiplication and division. Students also thought that mathematics is a difficult subject and tedious, because teachers rarely use the model of learning and use of media only using the environment around students. This study aims to determine whether there is any difference in learning outcomes of students who use and do not use media-assisted learning model TGT grain basket. This study uses a quantitative approach with experimental methods and research design quasi experiment. This research sample that is grade II totaling 50 students and consists of two classes. The results of this study were tested using paired samples test and obtained $t$ of 5.057 while $t$ table (sig. 0.05 and $\mathrm{df}=23$ ) of 2.069 which indicates thitung greater than ttable namely: 5.057> 2.069 which means that $\mathrm{HO}$ rejected and Ha accepted. So it can be concluded that there is a significant difference between the results of student learning to use and not use the media-assisted learning model TGT grain basket.
\end{abstract}

Keywords:

TGT, basket Grain, Learning Outcomes, Multiplication and Division,

\section{Pendahuluan}

Belajar adalah usaha sadar yang dilakukan dengan sengaja oleh seseorang yang ditandai dengan adanya perubahan menjadi lebih baik dari sebelumnya yang dilakukan dalam pendidikan formal maupun non formal. Perubahan tersebut merupakan pengalaman tingkah laku dari yang kurang baik menjadi lebih baik. Sedangkan pengertian belajar menurut Surya (2007:84) ialah suatu proses yang dilakukan oleh individu untuk memperoleh suatu perubahan tingkah laku yang baru secara keseluruhan, sebagai hasil dari pengalaman individu itu sendiri dalam interaksi dengan lingkungannya. Seseorang dikatakan belajar, jika ia terlibat langsung dalam proses pembelajaran dan ditandai dengan adanya perubahan menjadi lebih baik dari sebelumnya, baik dari segi tingkah laku, gaya berfikir, dan pengetahuannya yang bertambah.

Perubahan tingkah laku, gaya berfikir, dan pengetahuan yang bertambah inilah yang disebut hasil belajar. Gagne \& Briggs (dalam Jamil, 2013:37) berpendapat bahwa hasil belajar adalah kemampuankemampuan yang dimiliki siswa sebagai akibat berbuat belajar dan dapat diamati melalui penampilan siswa. Siswa akan lebih bersemangat belajar jika diberikan skor terhadap kemampuan atau keterampilan yang dimilikinya setelah mengikuti proses belajar. Pada saat belajar, jika seorang siswa mengetahui dirinya mengalami kemajuan dan peningkatan pada hasil belajarnya, maka ia akan lebih giat belajar untuk meningkatkan hasil belajarnya (Sardiman, 2009:94). Hasil belajar siswa menurut Benyamin Bloom (dalam Sudjana, 2009:22) dibagi dalam tiga ranah, yaitu: 1) ranah kognitif, berkenaan dengan hasil belajar intelektual (pengetahuan); 2) ranah afektif, berkenaan dengan sikap; dan 3) ranah psikomotorik, berkenaan dengan hasil belajar keterampilan dan kemampuan bertindak. Dari ketiga ranah hasil belajar tersebut, ranah kognitif merupakan ranah yang menjadi pusat perhatian guru, siswa, dan orang tua siswa untuk menentukan siswa tersebut mengalami peningkatan atau tidak setelah mengalami proses belajar. Untuk itu, dalam penelitian ini hanya fokus pada ranah kognitif (pengetahuan) siswa.

Faktor yang mempengaruhi hasil belajar siswa meliputi faktor internal dan faktor eksternal (Munadi dalam Rusman 2012:124). 1) faktor internal, adalah faktor-faktor yang muncul dari dalam diri seseorang, antara lain: faktor fisiologis, dan faktor psikologis. 2) faktor eksternal yang meliputi: faktor 
lingkungan, dan faktor instrumental. Hasil belajar siswa tidak hanya dipengaruhi oleh kualitas individu siswa itu sendiri, melainkan dipengaruhi oleh lingkungan disekitarnya.

Untuk memperoleh hasil belajar yang baik, pada saat belajar siswa harus berinteraksi dengan lingkungan kehidupannya sehari-hari, termasuk kegiatan berhitung. Berhitung merupakan kegiatan yang selalu dilakukan oleh setiap orang dalam semua aspek kehidupan, misalnya: kegiatan jual beli di pasar tradisional, menghitung pemasukan dan pengeluaran, kegiatan menabung, dan lain-lainnya. Kegiatan tersebut membutuhkan keterampilan berhitung yang benar. Untuk memperoleh keterampilan berhitung, siswa harus mempelajari ilmu berhitung. Salah satu ilmu yang mempelajari tertang ilmu hitung adalah matematika.

Matematika merupakan ilmu pengetahuan yang mempelajari struktur yang abstrak dan pola hubungan yang ada didalamnya (Subarinah, 2006:1). Sedangkan Prihandoko (2006: 1) berpendapat matematika merupakan ilmu dasar yang sudah menjadi alat untuk mempelajari ilmu-ilmu yang lain. Matematika adalah pelajaran yang sangat diperlukan di dalam dunia pendidikan. Dengan matematika, siswa dilatih untuk berpikir logis, sistematis, dan kritis. Selain itu, matematika melatih cara berpikir dan kemampuan penalaran siswa. Sehingga sangat berguna dalam menyelesaikan persoalan-persoalan dalam kehidupan sehari-hari (Solihah, 2016). Dalam pembelajarannya, matematika tidak berdiri sendiri melainkan terkait dengan konsep-konsep yang lainnya juga. Untuk itu, pembelajaran matematika seharusnya dapat menarik perhatian siswa, agar siswa mau belajar dan menggalih pengetahuan serta keterampilan berhitung mereka.

Berdasarkan hasil observasi yang dilakukan tanggal 26 November 2015 pada siswa kelas II SDN Saptorenggo 02 Pakis Kabupaten Malang, siswa-siswa cenderung kurang bersemangat saat belajar matematika dikarenakan, mereka beranggapan bahwa matematika adalah mata pelajaran yang membosankan, rumit dan sulit dimengerti. Khususnya pada materi perkalian dan pembagian, karena pada materi ini membutuhkan keterampilan berhitung, konsentrasi, dan pengulangan menghitung yang menyebabkan siswa malas dan enggan jika diminta guru untuk berhitung. Selain itu, siswa-siswa cenderung menggunakan metode menghafal dalam pembelajaran perkalian dan pembagian di kelas. Hal ini menyebabkan beberapa siswa kurang memahami konsep dasar perkalian yang merupakan penjumlahan berulang dan konsep dasar pembagian yang merupakan pengurangan berulang.

Pada pembelajaran matematika khususnya di sekolah dasar memerlukan kiat atau model pembelajaran tertentu yang dapat merangsang motivasi siswa untuk aktif belajar agar materi yang disajikan lebih mudah dipahami siswa ( Saptayanti, 2016). Sedangkan dilapangan pada saat membelajarkan matematika di kelas, guru jarang menerapkan model pembelajaran dan penggunaan media pembelajaran hanya memanfaatkan benda-benda yang ada disekitar siswa. Misalnya, menggunakan lidi untuk membelajarkan materi penjumlahan dan pengurangan. Penggunaan media pembelajaran dari benda-benda disekitar siswa dapat membantu siswa lebih memahami materi, akan tetapi media yang digunakan kurang menarik perhatian siswa. Jika pembelajaran di kelas dapat menarik perhatian siswa, maka siswa akan senang belajar dan lebih bersemangat menggalih pengetahuannya. Sehingga hasil belajar siswa juga akan mengalami peningkatan.

Salah satu cara yang dapat digunakan untuk menjadikan pembelajaran matematika menarik bagi siswa yaitu dengan menerapkan model dan media pembelajaran di kelas. Dalam penelitian ini, peneliti ingin mengetahui ada atau tidaknya perbedaan hasil belajar siswa kelas II yang menggunakan dan tidak menggunakan model pembelajaran Teams Games Tournament (TGT) berbantuan media keranjang bijibijian di SDN Saptorenggo 02 Pakis Kabupaten Malang. Untuk itu, penelitian ini hanya memfokuskan untuk meneliti penggunaan model pembelajaran tipe TGT yang dipadukan dengan media keranjang bijibijian.

Pengertian model pembelajaran TGT menurut Rusman (2012:224) adalah salah satu tipe model pembelajaran kooperatif yang menempatkan siswa dalam kelompok-kelompok belajar yang beranggotakan 5-6 siswa yang memiliki kemampuan, jenis kelamin, dan suku atau ras yang berbeda. Sedangkan Saco (dalam Rusman, 2012:224) mengatakan bahwa dalam TGT siswa memainkan permainan dengan anggota-anggota tim (kelompok) lain untuk memperoleh skor bagi tim mereka masing-masing. Pembelajaran kooperatif tipe TGT (Slavin, 2007:166-167) terdiri dari lima langkah, yaitu: penyajian kelas (class presentation), belajar dalam kelompok (teams), permainan (games), pertandingan (tournament), dan penghargaan kelompok (team reognition). Dalam model pembelajaran TGT, siswa dibagi dalam beberapa kelompok kecil yang anggota kelompoknya dipilih secara heterogen. Kelompok-kelompok ini akan belajar secara bersama-sama (teams) dan akan melakukan permainan (games) untuk menyelesaikan permasalahan, sedangkan tournament dilaksanakan setelah pembelajaran selesai. Model pembelajaran TGT menerapkan sistem pemberian skor, dengan tujuan agar siswa semangat belajar dan melatih siswa untuk berkompetisi dengan jujur. Selanjutnya kelompok yang mendapat skor paling banyak ditentukan sebagai pemenang dan mendapat hadiah dari guru. Model pembelajaran ini memiliki ciri-ciri: 1) siswa 
bekerja dalam kelompok-kelompok kecil; 2) games tournament; dan 3) penghargaan kelompok (Rusman, 2012:225).

Dengan menerapkan model pembelajaran TGT di kelas diharapkan dapat menghilangkan anggapan siswa tentang matematika adalah pelajaran yang membosankan. Karena dalam model TGT siswa belajar secara berkelompok, terdapat permainan yang berupa tournament, dan penghargaan untuk kelompok yang memperoleh skor terbanyak. Menurut Sudha (2016) dengan diterapkanya model pembelajaran kooperatif tipe Teams Games Tournamet (TGT) dapat membuat siswa untuk saling berkolaboratif dan memotivasi satu sama lain dengan kemampuan yang berbeda-beda, sehingga siswa dapat lebih tertarik, tidak mudah menyerah dan selalu aktif dalam mengikuti dan menyelesaikan tugasnya dalam proses pembelajaran. Selain itu, semua siswa terlibat secara aktif dalam pembelajaran, serta dapat menumbuhkan rasa kebersamaan dan saling menghargai sesama anggota kelompok (Shoimin, 2014:208). Model pembelajaran ini sangat sesuai jika diterapkan pada kelas yang memiliki kemampuan heterogen karena siswa yang kemampuannya kurang akan dibantu oleh siswa yang memiliki kemampuan baik pada saat kerja kelompok ( Sudimayasa, 2015). Sehingga siswa akan senang belajar matematika dan siswa lebih mudah memahami materi yang disampaikan guru. Jadi penerapan model TGT dalam pembelajaran matematika di kelas memiliki dampak positif bagi hasil belajar siswa.

Pembelajaran matematika di kelas akan lebih menarik dan menyenangkan jika memanfaatkan media dalam prosesnya. Media yang digunakan dalam pembelajaran disebut media pembelajaran. Penggunaan media pembelajaran sebaiknya disesuaikan dengan karakteristik siswa, agar siswa tertarik untuk belajar sehingga tujuan pembelajaran tercapai dengan maksimal. Salah satu karakter siswa kelas II yaitu masih suka bermain khususnya permainan yang berasal dari daerah mereka, salah satunya yaitu permainan congklak (dakon). Permainan congklak pada dasarnya menggunakan prinsip penjumlahan dan pengurangan, oleh karena itu permainan ini cocok digunakan sebagai media pembelajaran untuk siswa kelas II. Media pembelajaran yang menyerupai permainan congklak yaitu media keranjang biji-bijian.

Media keranjang biji-bijian merupakan perantara yang dimanfaatkan untuk menghubungkan materi ajar dengan siswa. Dengan adanya penggunaan media ini, siswa dapat menggalih pengetahuannya sendiri mengenai perkalian dan pembagian bilangan dua angka, dan siswa juga dapat menemukan konsep perkalian dan pembagian melalui pengalaman mereka. Media keranjang biji-bijian ini terdiri dari sepuluh buah keranjang dan biji-bijian sebagai pionnya. Bahan yang digunakan untuk membuat media ini, diantaranya: 1) 10 buah cetakan agar-agar berbahan plastik; 2) beras yang diwarna untuk menghias keranjang; 3) 10 buah kawat sepanjang $15 \mathrm{~cm}$ yang dihias dengan kertas berwarna; dan 4) beberapa biji buah asam sebagai pion.

Prinsip penggunaan media ini disesuaikan dengan tujuan pembelajaran perkalian dan pembagian bilangan sampai 2 angka, yaitu: siswa dapat memahami konsep dasar perkalian yang merupakan penjumlahan berulang dan konsep dasar permbagian yang merupakan pengurangan berulang, selain itu media ini juga dapat memudahkan siswa menyelesaikan permasalahan terkait perkalian dan pembagian. Tujuan utama penggunaan media keranjang biji-bijian ini yaitu untuk mengurangi kebiasaan menghafal perkalian dan pembagian yang sering dilakukan siswa. Cara kerja media ini sangat sederhana, untuk menyelesaikan soal perkalian, siswa hanya perlu memasukkan biji ke dalam keranjang dan menjumlahkan banyaknya biji pada seluruh keranjang. Sedangkan untuk menyelesaikan soal pembagian, siswa membagikan biji yang sudah disiapkan kedalam mesing-masing keranjang dengan jumlah yang sama, untuk menentukan hasilnya dengan cara menghitung jumlah biji pada masing-masing keranjang.

Pemanfaatan media keranjang biji-bijian dalam pembelajaran matematika dikelas dapat menghilangkan kesan matematika yang rumit dan sulit dimengerti. Karena dengan memanfaatkan media ini, siswa dapat secara langsung menggalih pengetahuan dan keterampilan berhitungnya, membuat materi yang abstrak menjadi konkret, dan siswa senang belajar karena disamping belajar mereka juga dapat bermain. Sehingga siswa lebih mudah memahami materi yang disampaikan guru. Jadi pemanfaatan media keranjang biji-bijian ini dapat memberikan dampak positif terhadap hasil belajar matematika siswa.

Berdasarkan latar belakang kurangnya ketepatan metode yang digunakan saat belajar perkalian dan pembagian siswa kelas II SDN Saptorenggo 02 serta kurangnya penggunaan model dan pemanfaatan media pembelajaran oleh guru, maka peneliti mengajukan judul "Perbedaan Hasil Belajar Siswa Materi Perkalian dan Pembagian Kelas II yang Menggunakan dan Tidak Menggunakan Model Pembelajaran Teams Games Tournament (TGT) Berbantuan Media Keranjang Biji-Bijian SDN Saptorenggo 02" yang bertujuan untuk mengetahui ada atau tidaknya perbedaan hasil belajar siswa materi perkalian dan pembagian kelas II yang menggunakan dan tidak menggunakan model pembelajaran Teams Games Tournament (TGT) berbantuan media keranjang biji-bijian SDN Saptorenggo 02 Pakis Kabupaten Malang. 
Hasil penelitian ini diharapkan dapat: 1) meningkatkan pengetahuan dan pemahaman guru tentang penerapan model pembelajaran TGT; 2) meningkatkanprofesionalisme guru dalam bidang pendidikan; 3) meningkatkan kreativitas guru dalam proses pembelajaran; serta 4) dapat dijadikan referensi bagi peneliti yang ingin melakukan penelitian tentang penerapan model pembelajaran TGT dengan memanfaatkan media keranjang biji-bijian di kelas, khususnya untuk mengembangkan pembelajaran matematika.

\section{Metode Penelitian}

Populasi dan sample dalam penelitian ini yaitu seluruh siswa kelas II SDN Saptorenggo 02 Pakis Kabupaten Malang tahun ajaran 2015/2016. Kelas II A berjumlah 26 siswa sebagai kelas kontrol, dan kelas II B berjumlah 24 siswa sebagai kelas eksperimen.

Instrumen penelitian yang digunakan dalam penelitian ini berupa tes hasil belajar. Tes adalah instrumen penelitian yang digunakan untuk mengukur hasil belajar (ranah kognitif) yang berupa pertanyaan atau soal. Tes ini berbentuk pre-test (untuk mengukur kemampuan awal siswa) dan post-test (untuk mengetahui pengetahuan yang diperoleh siswa setelah proses pembelajaran). Butir soal pre-test dan post-test dibedakan karena pada pelaksanaan pre-test siswa belum mendapat materi tentang perkalian dan pembagian, jadi untuk mengetahui kemampuan awal siswa, dapat diberikan soal penjumlahan dan pengurangan sebagai bekal mempelajari perkalian dan pembagian. Sedangkan soal posttest berisi tentang materi yang telah dipelajari siswa yaitu materi perkalian dan pembagian. Tes ini berbentuk soal pilihan ganda yang terdiri dari 15 soal dan soal uraian yang terdiri dari 10 soal.

Pengujian kualitas butir soal pada pre-test dan post-test dilakukan dengan analisis butir soal. Analisis butir soal bertujuan untuk mengadakan identifikasi soal-soal yang baik, kurang baik, dan soal jelek (Arikunto, 2012:222). Analisis butir soal yang digunakan untuk menguji instrumen tes ini, yaitu: uji tingkat kesukaran dan daya pembeda.

Tingkat kesukaran soal adalah pengukuran seberapa besar derajat kesukaran suatu soal (Arifin, 2009:266). Soal yang baik adalah soal yang tidak terlalu mudah dan tidak terlalu sukar (Arikunto, 2012:222). Uji tingkat kesukaran soal dalam penelitian ini dilakukan dengan cara menghitung proporsi siswa yang menjawab benar.

Perhitungan daya pembeda adalah pengukuran sejauh mana suatu butir soal mampu membedakan siswa yang sudah menguasai kompetensi dengan siswa yang belum menguasai kompetensi berdasakan kriteria tertentu. Soal yang baik adalah soal yang dapat dijawab dengan benar oleh siswa berkemampuan tinggi (Arikunto, 2012:226).

Penelitian ini menggunakan pendekatan kuantitatif dengan desain eksperimen, dan analisis menggunakan statistik uji t sampel berpasangan (Paired Sample T-Test). Metode yang digunakan untuk pengumpulan data yaitu metode eksperimen dengan desain penelitian semi eksperimen (quasi eksperimen). Desain penelitian semi ekperimen (quasi eksperimen) adalah desain penelitian yang mempunyai kelompok kontrol, tetapi tidak dapat berfungsi sepenuhnya untuk mengontrol variabelvariabel luar yang mempengaruhi pelaksanaan penelitian (Sugiyono, 2013:77). Penelitian ini dilakukan pada dua kelompok, yaitu kelompok ekperimen (kelompok yang diberi perlakuan) dan kelompok kontrol (kelompok pembanding atau kelompok yang tidak diberi perlakuan).

Setelah data terkumpul, perlu dilakukan uji hipotesis untuk menentukan hipotesis tersebut diterima atau ditolak. Pengujian hipotesis dalam penelitian ini, menggunakan uji t sampel berpasangan (Paired Sample T-Test). Sebelum data dianalisis, perlu dilakukan uji prasyarat analisis data, yaitu: uji normalitas. Dalam pengujian uji t sampel berpasangan, sebaran data harus berdistribusi normal. Sedangkan varian masing-masing variabel dapat sama atau tidak sama (Sarwono, 2009:134). Untuk itu, dalam penelitian ini uji prasyarat analisis data hanya menggunakan uji normalitas.

Uji normalitas digunakan untuk mengetahui sebaran data yang diperoleh berdistribusi normal atau tidak. Penelitian ini menggunakan uji normalitas Saphiro-Wilk dan penghitungannya menggunakan SPSS 16.0 for windows.

Uji hipotesis menggunakan uji t sampel berpasangan (Paired Sample T-Test) diolah dengan menggunakan aplikasi SPSS 16.0 for windows. Kesimpulan pengujian hipotesis dalam penelitian ini, yaitu: Jika $\mathrm{H}_{0}$ diterima, artinya tidak ada perbedaan yang signifikan antara hasil belajar siswa yang menggunakan dan tidak menggunakan model pembelajaran TGT berbantuan media keranjang biji-bijian. Sedangkan jika $\mathrm{H}_{0}$ ditolak, artinya ada perbedaan yang signifikan antara hasil belajar siswa yang menggunakan dan tidak menggunakan model pembelajaran TGT berbantuan media keranjang biji-bijian. 


\section{Hasil Dan Pembahasan}

\section{Hasil}

Pengujian kualitas butir soal tes dilakukan dengan analisis butir soal kriteria tingkat kesukaran dan daya pembeda dengan hasil, sebagai berikut: a) tingkat kesukaran soal pre-test terdiri dari: soal mudah sebanyak 6 butir atau 24\%, soal sedang sebanyak 13 butir atau 52\%, dan soal sukar sebanyak 6 butir atau 24\%. Tes tersebut berkualitas baik karena memiliki tingkat kesukaran yang seimbang. Sedangkan hasil uji daya pembeda, menunjukan bahwa soal pre-test memiliki daya pembeda yang rendah karena soal dengan kriteria daya pembeda cukup sebanyak 16 soal, sedangkan soal dengan kriteria daya pembeda baik sebanyak 9 soal; b) tingkat kesukaran soal post-test terdiri dari: soal mudah sebanyak 7 butir atau 28\%, soal sedang sebanyak 12 butir atau 48\%, dan soal sukar sebanyak 6 butir atau 24\%. Tes tersebut berkualitas baik karena memiliki tingkat kesukaran yang seimbang. Sedangkan hasil uji daya pembeda menunjukkan bahwa soal post-test memiliiki daya pembeda yang seimbang, karena soal dengan kriteria daya pembeda cukup sebanyak 13 soal, sedangkan soal dengan kriteria daya pembeda baik sebanyak 12 soal. berikut:

Hasil uji normalitas dengan menggunakan bantuan SPSS 16.0 for windows dengan hasil sebagai

Tabel 4.5 Uji Normalitas Data Kelas Kontrol dan Kelas Eksperimen

Tests of Normality

\begin{tabular}{lrrrrrrr}
\hline & \multicolumn{3}{c}{ Kolmogorov-Smirnov $^{\mathrm{a}}$} & \multicolumn{3}{c}{ Shapiro-Wilk } \\
& Statistic & $\mathrm{df}$ & \multicolumn{1}{c}{ Sig. } & Statistic & \multicolumn{1}{c}{ Df } & Sig. \\
\hline KONTROL & .120 & 24 & $.200^{*}$ & .961 & 24 & .450 \\
EKSPERIMEN & .146 & 24 & $.200^{*}$ & .954 & 24 & .322 \\
\hline
\end{tabular}

a. Lilliefors Significance Correction

*. This is a lower bound of the true significance.

(Sumber: hasil data diolah SPSS versi 16.0 for windows)

Berdasarkan tabel 4.5 menunjukkan hasil uji normalitas dengan Shapiro-Wilk diperoleh nilai sig. kelas kontrol dan kelas eksperimen sebesar 0,450 dan 0,322 yang artinya nilai sig $\geq 0,05$. Jadi dapat disimpulkan bahwa data dari kedua kelompok berdistribusi normal.

Hasil uji hipotesis menggunakan uji t sampel berpasangan (Paired Sample T-Test) yang diolah menggunakan bantuan SPSS 16.0 for windows dengan hasil sebagai berikut:

Tabel 4.6 Uji Hipotesis Kelas Kontrol dan Kelas Eksperimen.

Paired Samples Test

\begin{tabular}{|c|c|c|c|c|c|c|c|c|c|}
\hline & & Paired & Samples & Test & & & & & \\
\hline & & & $\mathrm{Pa}$ & red Diff & rences & & & & \\
\hline & & & $\begin{array}{c}\text { Std. } \\
\text { Deviati }\end{array}$ & $\begin{array}{l}\text { Std. } \\
\text { Error }\end{array}$ & $\begin{array}{r}95 \% \text { Con } \\
\text { Interval } \\
\text { Differ }\end{array}$ & $\begin{array}{l}\text { dence } \\
\text { f the } \\
\text { ace }\end{array}$ & & & $\begin{array}{l}\text { Sig. } \\
(2- \\
\text { taile }\end{array}$ \\
\hline & & Mean & on & Mean & Lower & Upper & $\mathrm{t}$ & $\mathrm{df}$ & d) \\
\hline Pair 1 & KONTROL - EKSPERIMEN & $\begin{array}{r}- \\
4.917\end{array}$ & 4.763 & .972 & -6.928 & -2.905 & $\begin{array}{r}- \\
5.057\end{array}$ & 23 & .000 \\
\hline
\end{tabular}

(Sumber: hasil data diolah SPSS versi 16.0 for windows)

Berdasarkan tabel 4.6 diperoleh thitung sebesar 5,057 sedangkan t tabel dengan sig. 0,05 dan degree of freedom (df) = 23 sebesar 2,069. Dari perolehan tersebut didapat hasil bahwa thitung lebih besar dari tabel yaitu: 5,057 > 2,069 yang artinya $\mathrm{H}_{0}$ ditolak dan $\mathrm{H}_{\mathrm{a}}$ diterima. Jadi dapat ditarik kesimpulan bahwa ada perbedaan yang signifikan antara hasil belajar siswa yang menggunakan dan tidak menggunakan model pembelajaran TGT berbantuan media keranjang biji-bijian. Pernyataan tersebut diperkuat oleh rata-rata 
nilai kelas eksperimen yang lebih tinggi dari pada rata-rata nilai kelas kontrol. Perhatikan tabel 4.7 berikut:

Tabel. 4.7 Rata-Rata Nilai Kelas Kontrol dan Kelas Eksperimen Paired Samples Statistics

\begin{tabular}{cccccc}
\hline & & Mean & N & Std. Deviation & Std. Error Mean \\
\cline { 2 - 6 } Pair 1 & KONTROL & 59.96 & 24 & 3.569 & .729 \\
& EKSPERIMEN & 64.88 & 24 & 3.012 & .615 \\
\hline
\end{tabular}

Berdasarkan tabel 4.7 diketahui rata-rata nilai pada kelas kontrol yaitu: 59,96. Sedangkan ratarata nilai pada kelas eksperimen yaitu: 64,88. Antara kelas eksperimen dan kelas kontrol memiliki perbedaan sebesar 4,92. Dari perbedaan rata-rata nilai tersebut dapat disimpulkan bahwa perbedaan hasil belajar siswa yang menggunakan model pembelajaran TGT berbantuan media keranjang biji-bijian dengan siswa yang tidak menggunakan model pembelajaran TGT berbantuan media keranjang biji-bijian sebesar $10,25 \%$.

\section{PEMBAHASAN}

Hasil uji normalitas menggunakan uji Saphiro-Wilk diperoleh nilai sig. kelas kontrol sebesar 0,450 . Sedangkan sig. kelas eksperimen sebesar dan 0,322. Nilai sig. tersebut lebih besar dari pada nilai $\alpha$ = 0,05 yang artinya data dari kedua kelompok berdistribusi normal.

Setelah melakukan perhitungan statistik menggunakan uji t sampel berpasangan (Paired Sample $T$-Test) diperoleh bahwa thitung $=5,057$ lebih besar dari pada tabel $=2,069$. Perhitungan tersebut menunjukkan bahwa $\mathrm{H}_{0}$ ditolak dan $\mathrm{H}_{\mathrm{a}}$ diterima yang artinya ada perbedaan yang signifikan antara hasil belajar siswa materi perkalian dan pembagian kelas II yang menggunakan dan tidak menggunakan model pembelajaran TGT berbantuan media keranjang biji-bijian di SDN Saptorenggo 02 Pakis Kabupaten Malang. Jadi dapat disimpulkan bahwa hasil belajar siswa yang menggunakan model pembelajaran TGT berbantuan media keranjang biji-bijian berbeda dengan hasil belajar siswa yang tidak menggunakan model pembelajaran TGT berbantuan media keranjang biji-bijian.

Selain itu, diperoleh juga rata-rata nilai kelas kontrol yaitu: 59,96. Sedangkan rata-rata nilai kelas eksperimen yaitu: 64,88. Antara kelas eksperimen dan kelas kontrol memiliki perbedaan sebesar 4,92. Dari perbedaan rata-rata nilai tersebut dapat disimpulkan bahwa hasil belajar siswa yang menggunakan model pembelajaran TGT berbantuan media keranjang biji-bijian lebih tinggi 10,25\% dari pada siswa yang tidak menggunakan model pembelajaran TGT berbantuan media keranjang biji-bijian.

Berdasarkan hasil ketiga perhitungan tersebut, menunjukkan bahwa ada perbedaan yang signifikan terhadap hasil belajar siswa yang menggunakan dan tidak menggunakan model pembelajaran TGT berbantuan media keranjang biji-bijian. Hasil penelitian ini didukung oleh pendapat Shoimin (2014: 20) bahwa untuk meningkatkan kualitas pendidikan agar lebih efektif dan efesien dapat dilakukan dengan melakukan pembaharuan dalam pembelajaran. Pembaharuan ini dapat dilakukan dengan cara menggali metode pembelajaran yang ada, sehingga dapat memunculkan model-model pembelajaran yang baru. Selain itu, dapat pula dilakukan dengan memadukan suatu model pembelajaran dengan media pembelajaran tertentu yang sesuai dengan materi yang akan diajarkan. Seperti yang dilakukan dalam penelitian ini, yaitu dengan memadukan model pembelajaran TGT berbantuan media keranjang biji-bijian. Hal ini dibuktikan adanya perbedaan hasil belajar siswa yang menggunakan model pembelajaran TGT berbantuan media keranjang biji-bijian lebih tinggi dari pada hasil belajar siswa yang tidak menggunakan menggunakan model pembelajaran TGT berbantuan media keranjang biji-bijian

\section{Simpulan}

\section{Simpulan dan Saran}

Berdasarkan hasil penelitian ini dapat disimpulkan bahwa $\mathrm{H}_{0}$ ditolak dan $\mathrm{H}_{\mathrm{a}}$ diterima yang artinya ada perbedaan yang signifikan antara hasil belajar siswa materi perkalian dan pembagian kelas II yang menggunakan dan tidak menggunakan model pembelajaran TGT berbantuan media keranjang biji-bijian di SDN Saptorenggo 02 Pakis Kabupaten Malang. Dari hasil analisis uji t sampel berpasangan (Paired Sample T-Test) diperoleh thitung sebesar 5,057 sedangkan tabel dengan sig. 0,05 dan df = 23 sebesar 2,069. Hal ini menunjukkan bahwa thitung $>t_{\text {tabel }}(5,057>2,069)$.

\section{Saran}


Berdasarkan kesimpulan tersebut, disarankan beberapa hal sebagai berikut:

1. Bagi guru, hendaknya bisa meningkatkan profesionalisme dalam bidang pendidikan, meningkatkan kreativitas dalam proses pembelajaran, dan memperbaiki proses pembelajaran di kelas dengan cara membuat pembelajaran lebih bervariasi. Guru bisa menerapkan model pembelajaran dan menggunakan media yang menarik dan sesuai materi yang akan diajarkan agar siswa lebih aktif dalam pembelajaran dan dapat meningkatkan hasil belajar siswa.

Bagi peneliti lain, kepada peneliti lain hendaknya melakukan penelitian serupa khususnya untuk mengembangkan pembelajaran matematika.di SD, tetapi dengan komponen yang berbeda agar hasil penelitian tentang model pembelajaran TGT berbantuan media keranjang biji-bijian lebih bervariasi.

\section{Daftar Pustaka}

Arifin, Zainal. 2009. Evaluasi Pembelajaran: Prinsip, Teknik, Prosedur. Bandung: PT Remaja Rosda Karya Arikunto, Suharsimi. 2012. Dasar-Dasar Evaluasi Pendidikan (Edisi 2). Jakarta: Bumi Aksara Arsyad, Azhar. 2014. Media Pembelajaran. Jakarta: Rajawali Pers

Asyhar, Rayandra. 2012. Kreatif Mengembangkan Media Pembelajaran. Jakarta: Referensi Jakarta Bungin, Burhan. 2011. Metodologi Penelitian Kuantitatif: Komunikasi, Ekonomi, dan Kebijakan Publik serta Ilmu-IImu Sosial Lainnya (edisi 2). Jakarta: Kencana

Cahya, Antonius. Prihandoko. 2006. Pemahaman dan Penyajian Konsep Matematika Secara Benar dan Menarik. Jakarta: Departemen Pendidikan Nasional

Congklak. Wikipedia. (online), (https://id.m.wikipedia.org/wiki/Congklak), diakses 03 Desember 2015

Hamdani. 2011. Strategi Belajar Mengajar. Bandung: Pustaka Setia

Kusdinar, Irwan. \& Zikri. 2009. Pintar Bermatematika 2. Jakarta: Depdiknas

Media Surya, H.M. dkk. 2007. Kapita Selekta Kependidikan SD. Jakarta: Universitas Terbuka

Pitajeng. 2006. Pembelajaran Matematika yang Menyenangkan. Jakarta: Depdiknas

Priliyani, Eka. Mujihardi. 2014. Penerapan Model TGT (Times Games Tournament) Menggunakan Media Monopoli Bilangan Materi Penjumlahan dan Pengurangan untuk Meningkatkan Keaktifan Siswa Kelas II SDN Kalirejo II Kabupaten Pasuruan. Skripsi tidak diterbitkan. Malang: FKIP Universitas Kanjuruhan

Rusman. 2012a. Belajar dam Pembelajaran Berbasis Komputer untuk Mengembangkan Profesionalisme Guru Abad 21. Bandung: Alfabeta

Rusman. 2012b. Model-Model Pembelajaran: Mengembangkan Profesionalisme Guru. Jakarta: Rajawali Pers Sanjaya, Wina. 2008. Strategi Pembelajaran: Berorientasi Standar Proses Pendidikan. Jakarta: Kencana Prenada Media Group

Saptayanti, Gusti Ayu Kade Emi, I Made Citra Wibawa, Ketut Pudjawan. 2016. Pengaruh Model Pembelajaran Kooperatif Tipe Tgt (Teams Games Tournament) Terhadap Hasil Belajar Matematika . e-Journal PGSD Universitas Pendidikan Ganesha Jurusan PGSD Vol: 4 No: 1

Sardiman. 2009. Interaksi dan Motivasi Belajar Mengajar. Jakarta: PT Raja Grafindo Persada

Sarwono, Jonathan. 2009. Statistika itu Mudah: Paduan Lengkap untuk Belajar Komputasi Statistik Menggunakan SPSS 16. Yogyakarta: C.V Andi Offset

Shoimin, Aris. 2014. 68 Model Pembelajaran Inovatif Dalam Kurikulum 2013. Yogyakarta: Ar-Ruzz Media

Slavin E. Robert.2007. Cooperative Learning: Riset dan Praktik. Bandung: Nusa Media

Solihah, Ai. 2016. Pengaruh Model Pembelajaran Teams Games Tournament (Tgt) Terhadap Hasil Belajar Matematika. Jurnal SAP Vol. 1 No. 1 Agustus 2016 ISSN: 2527-967X

Soekarman, F.I. dkk. 2013. Pedoman Penulisan Skripsi (edisi 3). Malang: Fakultas Ilmu Pendidikan Universitas Kanjuruhan Malang

Subarinah, Sri. 2006. Inovasi Pembelajaran Matematika Sekolah Dasar. Jakarta: Departemen Pendidikan Nasional

Sudha, I Kt., Kt. Gading, Ndara Tanggu Renda. 2016. Pengaruh Model Pembelajaran Teams Games Tournament Dan Motivasi Berprestasi Terhadap Hasil Belajar IPS Kelas IV. e-Journal PGSD Universitas Pendidikan Ganesha Jurusan PGSD Vol: 4 No: 1. 
Sudimahayasa, Nyoman. 2015. Penerapan Model Pembelajaran TGT Untuk Meningkatkan Hasil Belajar, Partisipasi, Dan Sikap Siswa. Jurnal Pendidikan dan Pengajaran, Jilid 48, Nomor 1-3, April 2015, hlm. 45-53.

Sudjana, Nana. 2009. Penilaian Hasil Proses Belajar Mengajar. Bandung: PT Remaja Rosda Karya

Sugiyono. 2013. Metode Penelitian Kuantitatif, Kualitatif, dan R\&D. Bandung: Alfabeta

Suprihatiningrum, Jamil. 2013. Strategi Pembelajaran. Yogyakarta: Ar-Ruzz

Supriyanto. 2014. Statistika Sosial: Untuk Penelitian Ilmu pendidikan dan Ilmu Sosial dilengkapi dengan Contoh Kasus dan Aplikasi SPSS. Malang: Program Pascasarjana Universitas Kanjuruhan Malang

Tanzeh, Ahmad. \& Suyitno. 2006. Dasar-Dasar Penelitian. Surabaya: Elkaf

Triyono. 2013. Metodologi penelitian pendidikan. Yogyakarta: Penerbit Ombak

Widiawati, Dewi. Sri. 2013. Penggunaan Media Permainan Congklak untuk Meningkatkan Hasil Belajar Siswa tentang Perkalian dan Pembagian dengan Tema Kerja Sama. Skripsi tidak diterbitkan. Bandung: Universitas Pendidikan Indonesia, (online), (http://repository.upi.edu/2021/penelitian tentang permainan dakon/congklak), diakses 25 november 2015 pukul 09.03

Wulandari, Novita. 2014. Penerapan Pembelajaran Kooperatid Tipe Times Games Tournament (TGT) Melalui Media Permainan Ular Tangga yang Dapat Meningkatkan Hasil Belajar IPA Siswa Kelas IV SDN Sumbersuko 02 Kecamatan Wagir Kabupaten Malang Tahun Pelajaran 2013/2014. Skripsi tidak diterbitkan. Malang: FKIP Universitas Kanjuruhan. 